Brane Senegačnik

\title{
Sofoklov in Senekov Kralj Ojdip: kulturnozgodovinski in individualni momenti hermenevtike
}

\section{UVOD}

Sodelovati na srečanju, na kakršnem smo zbrani, s temo, ki jo označuje naslov moje razprave, je po eni plati hvaležno opravilo, po drugi pa ne le nadvse problematično, temveč tako rekoč nemogoče. Moja razprava namreč govori o dveh delih, ki sta za nas v prvi vrsti literarna teksta (to pa zato, ker so pomembni integralni deli Sofoklove drame izgubljeni in je 'odrskost' Senekove še vedno vprašljiva), naslov srečanja pa je: interdisciplinarni znanstveni simpozij »Grčija skozi rimske oči v dobi cesarstva«. Ta oznaka sugerira, da naj bi pripovedovali relevantne stvari, ki jih bolj ali manj posrečeno imenujemo objektivne, se pravi preverljive, in pod določenimi razpoložljivimi pogoji splošno dostopne (z nedvoumno implikacijo, da morajo biti te stvari nove, še neznane ali celo izvirne, a zadnja kategorija spet zastavlja problem: problem razlikovanja med novim in izvirnim, o katerem tu ne bo mogoče razmišljati). ${ }^{1}$ Nisem prepričan, da lahko o literaturi govorimo na ta način: relevantno $\mathrm{v}$ najglobljem smislu in obenem znanstveno v pravem pomenu besede. Moja neprepričanost, ali bolje moje negativno formulirano stališče, seveda predpostavlja določeno prepričanje o tem, kaj je za literarni tekst relevantno $\mathrm{v}$ najglobljem smislu in zakaj ta njegova razsežnost ni znanstveno dosegljiva. Lahko bi rekel, da ima takšno dojemanje literatu-

1 Kako težko je začrtati razliko med tema pojmoma (in številnimi z njima povezanimi), lepo ilustrira knjiga Georgea Steinerja Grammars of Creation, ki ji niti po več kot tristo straneh nadrobnih analiz ne uspe jasno razmejiti koncepta "ustvarjalnosti« (creation) od koncepta »iznajdevanja ( vention). Prim. pronicljivo kritiko Franka G. Novaka v Studies in the Novel 34.4 (2002): 482. 
re zelo dolgo (čeprav pogosto povsem implicitno, teoretično neizoblikovano) tradicijo, da ni torej nič novega, ne radikalno izvirnega; po drugi strani pa je v relativno novem času, $v$ preteklem stoletju, več pomembnih mislecev različne duhovne provenience na izviren način formuliralo znanstveno nezapopadljivost literarnosti oziroma umetniškosti literarnih del. Prednjačili so fenomenologi: od Heideggerja, za katerega »se v umetnosti resnica kot neskritost bivajočega umešča $\mathrm{v}$ delo in nas same postavlja $\mathrm{v}$ neskritost, ki ji sledimo $"{ }^{2}$ in pisca najpomembnejše fenomenološke estetike Romana Ingardna, za katerega doseže literarna umetnina svoj vrh v razodetju 'metafizičnih kvalitet', "s katerih uzrtjem se dvigamo v praizvore biti, vendar tega uzrtja ne moremo sprožiti hote, temveč se nam razodevajo tako rekoč same od sebe le od časa do časa «; ${ }^{3}$ do najpomembnejšega slovenskega filozofa Franceta Vebra, ki je bistvo umetniškega dela videl v tem, da "pred nas obligatorično postavlja vsebinsko načelno neznanko sveta in življenja in izsiljuje jasno 'začutenje' še nekega posebnega in vsebinsko neizrekljivega dodatka - namreč transcendence ${ }^{4}{ }^{4}$

Podoben odnos do literature dajejo čutiti misli sodobnih literarnih teoretikov Georgea Steinerja o resničnih prisotnostih ali Hansa Ulricha Gumbrechta o trenutkih neposredne biti-v-svetu. ${ }^{5}$ Vendar bi rad tu predstavil neko drugo formulacijo. Iz tradicije, ki je znanstvenemu mišljenju veliko bliže, iz t. i. analitične filozofije izvira razmišljanje enega njenih najpomembnejših predstavnikov, ameriškega filozofa Donalda Davidsona, o metafori. ${ }^{6}$ "Metafora, « tako začne svoj spis anglosaksonsko trezni mislec, »je sanjsko delo jezika in njena interpretacija - kakor vsako sanjsko delo - zrcali ravno toliko o interpretu kolikor o tvorcu. Interpretacija sanj zahteva sodelovanje med sanjačem in budilcem, celo če sta ista oseba; samo dejanje interpretacije pa je delo imaginacije [ležeče B. S.]. Tako je tudi razumevanje metafore ravno toliko ustvarjalno prizadevanje, kolikor je tvoriti metaforo, tem ustvarjalnejše, čim manj ga vodijo pravila.« Pri takšnem izhodišču nas bržčas ne presenečajo njegovi sklepi, da "prvino novosti ali presenečenja v metafori vsakič znova izkušamo kot presenečenje «; $;^{7} \mathrm{da}$ »delovanja metafore ne more pojasniti nobena teorija metaforičnega pomena ${ }^{8}{ }^{8}$ in predvsem tale: "metafora navdihuje vpogled - tisto pa, kar s tem vpogledom opazimo, ni propozicionalno po svojem značaju. Skratka, ko skušamo opisati, na kaj nas je opozorila, opisovanju ni konca. Vsak poskus parafraziranja metafore se konča $\mathrm{z}$ besedami: in tako naprej. $\aleph^{9}$ Literarna besedila, seveda tudi Sofoklov in Se-

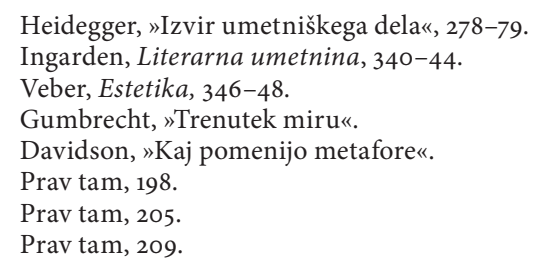


nekov Kralj Ojdip, so še posebej bogata z metaforami; a tudi druge figure so v literarnih besedilih uporabljene tako, da nas, kot pravi Ingarden, »že samo tematsko dojemanje njegove predmetne plasti sili v estetsko naravnanost «, ${ }^{10}$ se pravi v takšno branje, ki ni usmerjeno k iskanju objektivnih dejstev, temveč k dinamičnemu (in zato nenehno spremenljivemu) doživljanju njihove umetniškosti. Danes optimistične Ingardnove besede sploh niso več samoumevne, saj se je, denimo, fokus raziskovanja grške tragedije v zadnjih desetletjih tako rekoč povsem premaknil na socialni (oziroma kulturološki) kontekst: »Klio, Muza zgodovine, se je odločno premaknila na območje svoje tragične sestre Melpomene, " pravi Jasper Griffin, in »grška tragedija je postala politična zadeva« (to se pravi področje sociološko zamejene antropologije). V takšnem akademskem mnenjskem ozračju, dodaja, se že kaže, kako tak pristop postaja rigiden in se iskanje konsenza, ki nima absolutnih aspiracij, spreminja v ortodoksijo. ${ }^{11}$ Toliko o tem, zakaj mislim, da je problematično ali celo nemogoče znanstveno govoriti o bistvenih zadevah literature, in zakaj se mi zdi danes to potrebno omeniti.

Pravkar opisana znanstvena nedosegljivost literarnega teksta odseva $\mathrm{v}$ preprosti krilatici: Le style c'est l'homme même. Slog je tista temeljna hermenevtična kategorija (poleg strukturiranosti in pripadnosti zvrsti), ki kaže, da pravzaprav nobenega besedila, še posebej pa ne literarnega, ni mogoče zvesti na sistem jezikovnih pravil; subjekt, samozavedajoči se, konkretni človek ni njihova funkcija, temveč je kot njihov uporabnik v nenehoma spreminjajočih se situacijah kvečjemu vir sistemskih inovacij. ${ }^{12}$ Mutatis mutandis velja to tudi za razmerje med posameznikom in historičnimi, antropološkimi ali pa literarnozgodovinskimi sistemi, skratka, kategorija sloga kaže na nevralgično točko vsake modelne razlage literature. Vse to pa seveda ne pomeni, da literarna besedila ne nastajajo $\mathrm{v}$ historičnih kontekstih in $\mathrm{z}$ njimi povezanih jezikovnih konvencijah. Prav nasprotno: šele karseda natančen opis teh kontekstov (in tudi to je neskončno opravilo humanističnih in družboslovnih ved) lahko odpre možnost za relevantno in avtentično soočenje s slogom in tistim, česar pokazatelj je. $Z$ eno besedo: s tistim, kar tu imenujem »individualni momenti hermenevtike«. Dejansko je razpoznavanje slednjih izredno zahtevno, pa tudi delikatno opravilo, ki zahteva od literarnega znanstvenika gibanje po spolzkih tleh. Na takšnem obzorju razumevanja (ki seveda vključuje tudi samoraziskovanje literarnega raziskovalca) se raziskovanje vsakršnih kontekstov nastanka in recepcije literarnega dela ne kaže več kot poskus za umetniškost slepega zapopadenja le-tega, temveč kot razvijanje kulturnozgodovinskih momentov njegove hermenevtike.

10 Ingarden, Literarna umetnina, 426.

11 Griffin, "Sophocles and the Democratic City«, 73-74.

12 Za zgoščen sodoben prikaz hermenevtične teorije sloga prim. M. Frank, "Besedilo in njegov slog« in »Kaj je literarno besedilo in kaj pomeni njegovo razumevanje?«. 


\section{KULTURNOZGODOVINSKI MOMENTI SOFOKLOVE IN SENEKOVE DRAME}

Sofoklova in Senekova tragedija z naslovom Kralj Ojdip oziroma Oíítrous ó nevtike, zelo daleč vsaksebi. Pomen in oblike gledališča v družbah, v katerih sta nastala, so izredno različni navkljub tematski identiteti in nesporni kontinuiteti grškega in rimskega gledališča oziroma odločilnim vplivom atiškega gledališča na razvoj rimske dramatike. Nemalo specifik obeh del je nedvomno povezanih z različnimi kulturnimi in družbenimi funkcijami gledališča v okoljih, kjer sta nastali.

Atiško gledališče je bilo Dionizovo gledališče ne le v zunanjem, temveč tudi v najbolj notranjem pomenu: dramske predstave so nastale in vsaj vso klasično dobo ostale del obredja na čast temu bogu. Za monoteistično občutljivost pogosto nenavadno kritično prikazovanje božanskih dejanj in razmišljanje o njih ne izbrisujeta tega dejstva in mu tudi ne odvzemata pomena, pač pa postavljata pred interpreta posebne hermenevtične zahteve. Tudi sloviti presenečeno ogorčeni vzklik atenskih gledalcev: »Kaj ima vse to opraviti $\mathrm{z}$ Dionizom? $\ll,{ }^{13} \mathrm{ki}$ je bil in še vedno je tema številnih ambicioznih teorij, ${ }^{14}$ ne

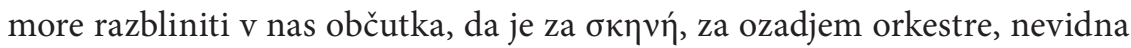
realnost, ki deluje v vidni in vanjo vstopa; z glasom daimoniona, ki se mu zdi kot njegov lastni glas, nezadržno kliče človeka k sebi, obenem pa mu - z ognjenim mečem tragičnih udarcev - nenehoma brani, da bi prestopil vanjo. In to navkljub temu, da vzdušje ob velikih praznovanjih, posvečenih bogu vina, zelo verjetno ni bilo svetostno zadržano, temveč je bilo prej tako, kot ga opisuje A. Sommerstein: Prevladujoča moška družba, množičnost, nizka povprečna starost, navdušenje nad alkoholnimi osvežili, pogosta konfrontacija z nastopajočimi (žvižgi, aplavzi, metanje predmetov na oder) in celo potreba po strogem nadzoru publike - zaradi vsega tega je vzdušje v Dionizovem gledališču najbrž prej spominjalo na nogometni stadion San Siro kot na

13 Te besede so pravzaprav pregovor, katerega izvor in smisel so že v antiki različno razlagali. Obstajal je v dveh različicah. Plutarh (Symp. Quaest. 1.1.5), ki ga navaja v obliki: »Kakšno zvezo ima to z Dionizom? «, piše, da izvira iz ust gledalcev, presenečenih nad tragedijami Friniha in Ajshila, ki sta v to zvrst prva uvedla mit in trpljenje junakov. Pri Zenobiju 5.40 in v leksikonu Suda pa se glasi: »Nič v zvezi z Dionizom. «Prvi razlaga njegov izvor podobno kot Plutarh in dodaja, da je bila takšna reakcija gledalcev razlog za uvedbo satirske igre, ki je bila motivno tesneje povezana z Dionizovim kultom. Suda pa navaja dve razlagi: po prvi naj bi Epigen iz Sikiona napisal na čast Dionizu tragedijo, ki pa (motivno, tematsko) ni bila povezana z njim. Po drugi, ki se očitno naslanja na Aristotela (kot vir navaja njegovega učenca Kameleona), pa je izrek nastal, ko so avtorji satirskih iger prešli k prikazovanju mitov in zgodb, v katerih ni bilo Dioniza. Za razlago prim. Pickard-Cambridge, Dithyramb, Tragedy and Comedy, 166-68. Pickard-Cambridgeev povzetek se glasi, da nihče ni natanko vedel, od kod reklo izvira.

14 Povezava tragedije z Dionizom in njegovim kultom je ena zelo pomembnih tematskih točk literarnozgodovinskega raziskovanja antične dramatike in sodobnih klasičnih študij. Znanstvena literatura na tem področju je zato kajpak preobsežna, da bi jo lahko tu navedli. Za zgoščen in precizen, pa tudi izviren in polemičen prikaz sodobne vloge dionizičnega elementa v tragediji prim. R. Friedrich, »Everything to Do with Dionysos?«, in Seaford, »Something to Do with Dionysos«. 
Teatro alla Scala. ${ }^{15}$ Nasprotno pa je verodostojnost Livijevega poročila o religioznih izvorih gledališča v Rimu sumljiva ${ }^{16}$ (vzrok temu je poleg časovne oddaljenosti tudi njegova ubranost s postavkami programa Avgustove moralne prenove). ${ }^{17}$ Celo če so v kasnejših časih gledališke igre postale sestavni del državnih praznovanj na čast bogovom, ${ }^{18}$ niso imele takšne vloge kot tragiški agoni v klasičnih Atenah. Nekatere pomembne javne prireditve (zlasti pogrebi in slavnostni triumfi) v Rimu so res imele v sebi nekaj prateatralnega, bile so, lahko rečemo, režirane, čeprav v Rimu še ni bilo gledaliških predstav, ${ }^{19}$ in so bile kasneje tako rekoč naravno dopolnjene $\mathrm{z}$ dramskimi igrami: toda to je sodilo bolj k spektakelskim razsežnostim, ki so le ena in (morda ne nujno bistvena) sestavina gledališkega dogodka.

Nadalje je pomembna razlika tudi v političnem pomenu. Dionizovo gledališče je lahko sprejelo do 15.000 ljudi in ni verjetno, da bi bilo kdaj zelo prazno; potemtakem je 'gledališka publika' vselej zajemala velik del celotnega atenskega prebivalstva, najbrž nikdar manj kot $20 \%$, pogosto pa kar od 40-50\% (vseh prebivalcev je bilo v 5. stoletju med 120.000 in 180.000 , moških okrog 30.00o). Verjetno je bila prisotnost v gledališču še večja kot na običajnem zborovanju skupščine, zato je bila to idealna priložnost za dajanje političnih izjav (in tudi ne preseneča, če so se igralci v komediji, kjer so žanrske konvencije pač to dopuščale, redno obračali na publiko, kot da ta predstavlja celotno atensko prebivalstvo). ${ }^{20}$

Čeprav je znano, da je imela drama tudi v Rimu politično funkcijo (v 3. in 2. stoletju pr. Kr. predvsem za oznanjanje starih rimskih kreposti, v kasnejšem času republike pa je rabila za politični boj med posamezniki, ki so skušali prek dramskega medija diskreditirati drug drugega: Marij, Sula, Pompej, Cezar, Oktavijan), pa ta funkcija ni mogla imeti tako središčnega pomena, kot ga je imela v Atenah. V Rimu je bilo gledališče bolj pomožno sredstvo kot oblika političnega delovanja. K razumevanju tega lahko pripomore tudi, če pomislimo na velikost gledališč. Rim je imel več velikih gledališč: Pompejevo je sprejelo 11.000 gledalcev, Balbovo 7000 in Marcelovo kar 13.000 (1. stoletje pred Kristusom), v času cesarja Avgusta pa je, če gre verjeti podatkom, samó zastonjsko žito prejemalo kar 200.000 ljudi. Razmerje med gledališkimi kapacitetami in prebivalstvom je torej še vedno v prid Aten, predvsem pa rimska gledališča niso imela enakega družbenega statusa kot Dionizovo v Atenah.

15 Sommerstein, Theatron, 18. Prim. tudi Sommerstein, Aeschylean Tragedy, 50-51.

16 Tit Livij, Ab urbe condita 7.2.1-13.

17 Ivanc, "Medeja: rimska tragedija«, 104.

18 Npr. igre ludi Florales konec aprila in v začetku maja, posvečene Flori; ludi plebei v novembru, posvečene Jupitru; ludi Apollinares v juliju, posvečene Apolonu; ludi Megalenses v aprilu, posvečene Veliki materi (Magna Mater); Cerealia v aprilu, posvečene Cereri. Igre so uprizarjali tudi ob triumfih, posvetitvah templjev in ob pogrebih.

19 Ivanc, "Medeja«, 106-7: pri tem so se uporabljale maske, rekviziti, celo deus ex machina (v gledališču pa - tako gramatik Diomed - šele v 1. stoletju pr. Kr.), zbor, glasba, monologi.

20 Sommerstein, Theatron, 17-18. 
Odnos povprečnega Rimljana do gledališča je bil zelo drugačen od odnosa Atenca v klasični dobi. Za to so obstajali povsem praktični vzroki. Čeprav so verjetno že v klasični dobi $v$ Dionizovem gledališču solistične vloge igrali profesionalci, ki niso bili nujno Atenci, je namreč vseeno veliko gledalcev imelo odrsko izkušnjo: na predstavah v kateri od gledaliških zvrsti - tragediji, komediji, satirski igri ali ditirambu - so že kdaj nastopili sami ali pa njihovi najbližji družinski člani. $\mathrm{V}$ dramskih in ditirambskih zborih je namreč samo v enem letu nastopilo 665 moških in 500 dečkov! ${ }^{21} \mathrm{~V}$ Rimu takšne osebne povezave državljanov z gledališčem ni bilo. Že omenjeno Livijevo poročilo je veliko verjetnejše glede izvora dramskih predstav (ki so bile, če mu gre verjeti, spočetka pravzaprav baletne predstave): »Stvar je bila tujega izvora«, izvajali so jo igralci iz Etrurije. Resda tudi oblike, iz katerih se je razvila atiška dramatika, niso bile avtohtone: ditiramb je prinesel iz Korinta v Atiko pesnik Lasos (iz Hermione), tudi faloške pesmi so morda prišle s Peloponeza in iznajditelj satirske igre pesnik Pratinas je bil doma iz Fliunta, ki prav tako leži na Peloponezu, ${ }^{22}$ vendar imamo tragedijo in komedijo klasičnega obdobja upravičeno za atiški stvaritvi, ne le $\mathrm{v}$ jezikovnem, ampak tudi v splošnem kulturnem in idejnem oziru. Zlasti v t. i. patriotskih igrah je dobila ideologija filatenajstva posebno močan (in seveda umetniško dognan) izraz; te tragedije, nekatere med njimi sodijo med najpomembnejša dela antične in svetovne književnosti, ${ }^{23}$ brez te ideološke komponente sploh niso razumljive. Najbrž bi za dela rimske tragedije le težko trdili kaj podobnega. V okviru le-te se je sicer izoblikovala t. i. fabula praetexta, zgodovinska drama, ki je zajemala snov iz rimskega okolja, vendar je naše presojanje le-te skrajno oteženo, saj se je ohranilo zgolj eno delo: Octavia, ki so jo do nedavnega pripisovali Seneki. Toda že dejstvo, da je obstajala poleg nje tudi t. i. fabula cothurnata, tj. tragedija s snovjo iz grške mitologije, sugerira, da tragedija najbrž nikoli ni bila tako intimno povezana $\mathrm{z}$ rimsko kulturo, kot je bila $\mathrm{z}$ atiško.

\section{SENEKOV OJDIP: 'PRAVA' ALI BRALNA DRAMA?}

Poleg vseh opisanih razlik v družbenem in kulturnem statusu atenskega in rimskega gledališča je treba med 'zunanjimi' kulturnozgodovinskimi momenti hermenevtike obeh dram omeniti še vprašanje, ali so Senekove tragedije sploh res drame v pravem pomenu besede, namreč dela, namenjena

21 Senegačnik, »Klasična atiška tragedija«, 83.

22 Tako leksikon Suda v njemu posvečenem geslu. Prim. tudi Pickard-Cambridge, Dithyramb, Tragedy and Comedy, 92-96.

23 Tu nimam v mislih le tistih Evripidovih tragedij iz prvih let peloponeške vojne, ki jih običajno označujejo z izrazom "patriotske» (ali tudi "politične») igre, kot so npr. Heraklidi in Prošnjice (prim. Knox, CHCL I, 318; Zuntz, The political plays of Euripides), ampak tudi in predvsem tiste igre vseh treh velikih tragiških pesnikov, v katerih so miti prirejeni tako, da proslavijo atensko polis, bodisi da izvorno neatenski mitični junak tam doseže odrešitev (Oresteja) bodisi da tam končno najde zatočišče, dobi svoj kult in postane zaščitnik Aten (Medeja, Ojdip v Kolonu). 
igrani uprizoritvi, ali pa so zgolj bralne drame, namenjene recitaciji. ${ }^{24}$ Pogledi na to niso enotni in se skozi čas spreminjajo ${ }^{25}$ podobno kot vpliv in slava njihovega avtorja. V nasprotju s Sofoklom, ki sicer tudi ni užival enake priljubljenosti v vseh zgodovinskih obdobjih, a je njegov Kralj Ojdip nedvomno ena najjasnejših zvezd stalnic na evropskem gledališkem nebu, ${ }^{26}$ je Senekova zvezda včasih prav tako močno potemnela, kot je drugič žarela. Glavni navdihovalec elizabetinskih dramatikov (to pomeni seveda tudi in predvsem Shakespeara) je bil za A. W. Schlegla samo »votla hiperbola v primerjavi z najbolj notranjo resnico grških tragikov $«{ }^{27}$ za Butlerja pa glavni krivec, da je evropsko dramo od renesanse do druge polovice 19. stoletja zaznamovala čezmerna prevlada deklamatorične retorike. ${ }^{28}$ Pravzaprav sta vprašanje o naravi Senekove dramatike in vprašanje njene vrednosti med seboj tesno povezani, obe pa sta bistveno odvisni od predstav posamezne dobe o gledališču, pa tudi od obzorja, v katerem ljudje nekega časa gledajo umetnost in kulturo. Ne vemo sicer, ali so bile Senekove drame za njegovega življenja uprizorjene ali ne, zanesljivo pa vemo, da so bile kasneje: v renesančni Evropi, v Angliji za časa dinastije Tudorjev. In navsezadnje ni brez pomena, da se uprizarjajo tudi danes v Italiji, Franciji in Švici. Tako je bil leta 1968 v Londonu (Old Vic Theatre) uprizorjen tudi Ojdip v priredbi znanega pesnika Teda Hughesa. ${ }^{29}$

Toda to je, kot rečeno, stvar spremenljivega okusa in razumevanja kulture. V sodobnem gledališču je pravzaprav malo stvari, za katere bi lahko rekli, da so neuprizorljive (razen morda pri zelo tradicionalnih postavitvah). Vsekakor pa zahteva uprizoritev Senekove drame zelo drugačno koncepcijo gledališča: zlasti zelo drugačen, bistveno bolj privilegiran položaj besede. Tu pa se odpira naslednji vidik, ki omejuje možnost neposredne primerjave: različne estetske koncepcije in intencije določajo različno dramaturgijo in ekonomijo izraznih sredstev obeh avtorjev. Čeprav je Senekov Ojdip skoraj 500 verzov krajši od Sofoklovega, se zdi, da je v njem veliko več besed; da je v njem vsaka stvar detajlno naslikana $\mathrm{z}$ besedami, ki kar vrejo in se komajda stisne-

24 Na neki način to vprašanje sicer sodi k estetski koncepciji drame, kar v Senekovem času zagotovo pomeni, da je tudi stvar njegove estetske odločitve, in ga moramo potemtakem šteti k individualnim hermenevtičnim momentom, vendar je nedvomno povezano tudi z družbenim in kulturnim statusom gledališča v eni in drugi družbi in s predstavami, ki so jih imela različna obdobja o tem, kaj gledališče sploh je.

25 Prim. instruktivne pripombe G. Steinerja, Smrt tragedije, 17-18, na to temo: "Zaradi napačno razumljenega odlomka iz Livija so srednjeveški komentatorji predvidevali, da je igre Seneke in Terencija pripovedoval recitator, verjetno kar sam pesnik. Italijanski poznavalci so že leta 1315 in okoli 1387 napisali latinski tragediji po Senekovem vzoru, vendar nobena ni bila namenjena odrski uprizoritvi. Tako je občutenje tragičnega ostalo razločeno od gledališča. Neka pripomba v Erazmovem delu Adagia pa daje slutiti, da še v šestnajstem stoletju poznavalci klasike niso bili prepričani, ali so bile grške in rimske tragedije sploh namenjene dramski uprizoritvi."

26 Še najbolj nenavadno pri usodi te drame se zdi, da ob prauprizoritvi ljubljenec atenskega občinstva Sofokles z njo ni odnesel prve nagrade, ki jo je sicer prejel kar 24-krat (od tega šestkrat na lenajskih praznikih); bolj kot njegova mojstrovina je žirijo navdušilo danes neznano delo sicer izjemno plodnega Ajshilovega nečaka Filokla.

27 Schlegel, »Vorlesungen über dramatische Kunst und Literatur«, $234=$ "Senecas Tragödien«, 13.

28 Post-Augustan Poetry, nav. po: Eliot, »Wesen, Tugenden und Schwächen«, 22.

29 Boyle, Roman Tragedy, 189-93; glej tudi 268, op. 9. 
jo v vrstice. V zvezi s Senekovo dramatiko je T. S. Eliot napisal: »Ne smemo

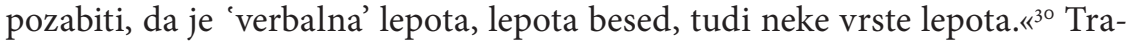
dicionalno naravnana estetika, ki v umetnosti išče lepoto, se mora nedvomno tudi pri Senekovem Ojdipu odpraviti v to smer. Po svoji zgradbi to delo namreč zagotovo ne nudi tistih efektov, ki jih neizbežno išče 'tradicionalna' dramaturgija.

\section{INDIVIDUALNI MOMENTI HERMENEVTIKE: SENEKOVA RETORIZACIJA OJDIPA}

Ali sodi psihološka obravnava dramskih likov na področje pesnikove individualne poetike? Prav gotovo je res odvisna od njegove dramaturgije in od njegove koncepcije gledališča, ti pa sta seveda povezani z gledališko prakso njegovega časa, s statusom gledališča, pa tudi s splošnim kulturnim obzorjem družbe. A popolna fiksiranost na 'zunanje', družbene in kulturne dejavnike na koncu privede do absurdnega zaključka, da dram ne pišejo avtorji, individualni ljudje, temveč družbenozgodovinske okoliščine; takšen je praktičen (seveda neartikuliran) rezultat nemajhnega dela trendovskih socio-antropološko orientiranih literarnih raziskav. Zato je ob skrbnem motrenju vpliva družbenih kontekstov in vzorcev kulturne in literarne tradicije vendarle treba tvegati poskus, da opredelimo tudi individualni, avtorski prispevek pisca. Zdi se, da je inventivno, slikovito upodabljanje notranjosti, včasih pa že pravcato anatomiziranje duševnosti dovolj izrazita poteza Senekovega opusa v celoti, da smemo razgibanost notranjega življenja njegovih dramskih likov v večji meri pripisati njegovemu osebnemu zanimanju in individualni poetiki kot žanrskim standardom rimske dramatike.

\section{a) Psihologija glavnega lika}

Po psihološki plati zaznamuje Senekovega Ojdipa čudna dvojnost: svet dramskih likov, ki je nedvomno razdelan veliko nadrobneje in prikazan bolj reliefno kot pri Sofoklu, mestoma vendarle zaznamujejo nenavadne besede in poteze, ki bolj kot psihološki logiki sledijo zahtevam retorične efektnosti. Čeprav gre tu za 'principialno' drugačnost, za drugačno dramaturško tehniko in perspektivo prikazovanja likov kot $\mathrm{v}$ atiški drami, pa ne moremo spregledati tudi neke temeljne 'vsebinske' razlike $\mathrm{v}$ psihologiji obeh naslovnih likov. V nasprotju s samozavestnim Sofoklovim Ojdipom je Senekov že na začetku naveličan vladanja in prestrašen zaradi oraklja, še več: vsega se boji ${ }^{31}$ in ne zaupa samemu sebi. ${ }^{32}$ Njegove glasne tožbe vznemirijo Jokasto, ki ga mora

30 Eliot, »Wesen, Tugenden und Schwächen«, 24.

31 Prim. 27: "cuncta expavesco

32 Prim. 24: "parum ipse fidens mihimet«; 27: "meque non credo mihi«. 
opomniti na brezplodnost in celo nemoškost tarnanja..$^{33}$ Vse to je tako daleč od Sofoklovega junaka, kot si sploh lahko zamislimo. Čeprav se 'rimski Ojdip' na to odzove zelo retorično impulzivno in zatrdi, da se ne boji ne Marsove strašne sile ne Gigantov, kakor se nekoč tudi ni prestrašil Sfinge in ni pobegnil pred »krvavimi čeljustmi okrutne pevke«, pa že naslednji hip sam pri sebi obžaluje, zakaj je zamudil priložnost in se ni pustil zviti pošasti pokončati! In ko vzklikne: »To tebansko žezlo je nagrada za tvoje slavno delo, za uničenje Sfinge, « je to jedek sarkazem obupanca, ki je že davno izgubil vero v lastno veličino. Tebansko žezlo, kraljeva oblast, pomeni namreč samo zlo: plod njegove zmage, prah uničene pošasti zdaj s svojo kužno močjo uničuje Tebe. ${ }^{34}$ Le kakšno rešitev bi lahko prinesel Apolon državi s tako zdvomljenim in globoko resigniranim vladarjem? Senekov Ojdip, ki se čudi, kako da mu kuga še prizanaša in kakšen zli namen usode je v tem; ${ }^{35}$ ki verjame, da je Apolonova prerokba že obsodba, ${ }^{36}$ in se boji tudi tistega, kar ima za neverjetno, se zdi kaj slaba opora Tebancem v času kuge in je v tem pogledu pravcati negativ svojega samozavestnega 'atenskega prednika', ki sodržavljanom zbuja neomajno zaupanje. Tudi on sicer trpi, a njegova žalost in bolečine, ki celo presegajo trpljenje vseh drugih, so izraz plemenite vladarske skrbi za podložnike. ${ }^{37}$

Takšna ekspozicija nima posledic le za psihologijo, temveč tudi za dramaturgijo: psihološka drugačnost glavnega lika ne vpliva le na odnose drugih likov do njega in s tem na neki način na vzdušje v celotni drami, temveč je pomembna tudi za dramaturško zgradbo. Iz takšne zasnove dogajanja seveda ne more rasti napeta zgodba: Ojdip je namreč tako rekoč že v začetku na tleh. Kakor koli strašna so dejanja, ki jih je zagrešil v preteklosti, ga kasnejše razkritje le-teh potisne samo še globlje v psihično bedo, v katerih je globoko tičal - ne, v kateri se je utapljal že prej.

\section{b) Dramaturgija: ekstenzija motiva in ekskurz}

Seneka potegne takoj na začetku drame še eno potezo, ki onemogoči, da bi se dramaturški lok napel tako kakor pri Sofoklu. Ta poteza je njegov prikaz nesreče, ki je zadela Tebe. Rimski dramatik tu seveda ne uvede - kakor stori večkrat kasneje - motivne novosti, pač pa enega od konstitutivnih elementov mita prikaže izrazito ekstenzivno in mu $\mathrm{z}$ vsemi silami svoje poetične imaginacije da tolikšen poudarek, da se klobčič dramskega dogajanja sploh ne more zares dinamično odviti. Opis nesreče, kuge, ki pustoši tako prebi-

33 Prim. 82-86.

34 Prim. 106-8.

35 Prim. 31: »cui reservamur malo?«

36 Prim. 34: "scilicet Phoebi reus«. Prim. tudi komentar N. Treveta Commento all' Oedipus di Seneca, ad loc.: »id est iudicatus reus a Phebo, qui tot mala vaticinatus est de te« (»kriv po sodbi Apolona, ki je o tebi prerokoval toliko zlih stvari«).

37 Prim. OT 58-67. 
valstvo $^{38}$ kot živali, ${ }^{39}$ rastlinstvo in 'neživo' naravo, ${ }^{40}$ po dolžini in silovitosti besed daleč presega Sofoklovega. Kugo najprej v skoraj petdesetih verzih naslika Ojdip, ${ }^{41}$ potem nam v tako rekoč reliefni obliki stopi pred oči, ko se v še daljši lamentaciji zbora zvrsti pred nami dolga procesija osupljivo temačnih podob. ${ }^{42}$ Vse polno je zlih znamenj (pri obredu žrtvovanja bik pogine, še preden ga zadene svečenikova sekira; drugemu iz rane ne brizgne kri, temveč črna kužna brozga) ${ }^{43}$ in strašljivih prikazni (sam Kerber naj bi se strgal s peklenske verige in se klatil po okolici Teb, po gozdovih naj bi tavale postave mož nadčloveške velikosti, reka Dirka naj bi dvakrat postala krvava); umiranje, poginjanje in propadanje je naslikano $\mathrm{z}$ izjemno otipljivostjo in pretresljivostjo, ki presega morebitne vzornike. ${ }^{44}$ Tolikšna nasičenost $\mathrm{z}$ grozo in obupom že v samem začetku zagotovo zmanjšuje bralčevo (gledalčevo) občutljivost za Ojdipovo osebno tragedijo, razpoložljivost za občutja strahu in usmiljenja, ki naj bi jih vzbudila usoda glavnega lika.

Na drugi strani pa imamo tu priložnost (eno od neštevilnih sicer, a še neodkrito ali vsaj ne dovolj poudarjeno), da občudujemo Sofoklovo mojstrsko dramsko arhitektoniko. Zevsov duhovnik opiše nesrečo skrajno ekonomično, a vendarle mu v borih devetih verzih uspe ustvariti plastičen vtis o tako rekoč kozmičnih razsežnostih katastrofe, v katero so nepomogljivo ujete Tebe..$^{45}$ Ojdipova mogočna in čvrsta postava daje upanje, da bo zajezila krvavo morje zla; tako velika je, da pritegne nase vso pozornost, a obenem ne zastre trpljenja mesta v ozadju. Je resnična pogonska sila vsega dogajanja; ko se zlomi v strašnem samospoznanju, stoji točno v žarišču gledalčevega (bralčevega) pogleda: noben estetski, retorični ali motivni ekskurz je ne zastira s svojo senco. V svoji popolni ponižanosti pa postane nekakšno vzvratno zrcalo, v katerem še jasneje in nazorneje uzremo grozljivost opustošenja tebanske polis.

Seneka pa je v obstoječi mit, kakor ga poznamo iz Sofoklovega 'izvirnika', vnesel tudi več novosti, povezanih s preroško dejavnostjo: poleg uvedbe novega lika, hčerke preroka Tejrezija, Manto, sta to dva ekskurza - o vedeževanju iz drobovine in o nekromantiji (2., 3. dejanje). Novi elementi seveda

38 Prim. 29-30: »ista Cadmeae lues / infesta genti«; prim. tudi 52-70; 110-131; 180-201.

39 Prim. 132-53. Onemoglost napadalnih plenilcev - volkov, levov, medvedov, kač - je seveda nekaj povsem drugega kot 'pastoralno' sožitje govejih čred in levov v Vergilijevi Četrti eklogi, prim. v. 22.

40 Prim. 37-49.

41 Prim. 32-80; 154-62.

42 Prim. 110-201.

43 Prim. 132-41.

44 Zlasti Lukrecij 6.1138-1286 in Tukidid 2.47-55. Naj prav v zvezi s tem primerom opozorim na poglavitni problem razlage literature z modeli: veliko nezanesljivega predpostavljanja. Prvič: težko je dokazati, da sta omenjena opisa rabila kot 'modela' ne le Seneki, ampak tudi njegovemu občinstvu (kar je za delovanje literarnega modela nujno). Drugič: še teže je utemeljiti predpostavko, da je Seneka epski oziroma historiografski model prilagodil dramskemu modelu prikaza, saj nimamo nobenih dokazov za obstoj takega modela; še več, zdi se, da so njegova dramaturška koncepcija in pesniški postopki izrazito individualni, torej ne-modelni.

45 Prim. OT 22-30. 
vplivajo na zgradbo drame, ${ }^{46}$ predvsem pa znatno upočasnjujejo tempo dejanja. Z njimi pesnik ne razkazuje toliko svoje učenosti o 'svetih praksah', kot nanaša še temnejše tone - in včasih že kar bizarne motive - na podobo celote. Pri vedeževanju iz drobovja npr. v telesu junice najdejo plod $^{47}$ in ugotovijo, da notranji organi niso na svojem mestu, temveč so zamenjali naravni položaj (pljuča niso na desni, srce ne na levi). Skratka, živalska notranjost je alegorija posledic Ojdipovega dejanja: mutatus ordo, natura versa est (»red je sprevržen, narava je obrnjena na glavo«). $4^{8}$

Podvojitev vedeževalnega obreda je sicer utemeljena: haruspicium, ki ga izvajata Tejrezias in njegova hči Manto, ne da dokončnega odgovora, zato pošljejo Kreonta prisostvovat nekromantiji, ki po slikovitosti, pa tudi srhljivosti daleč presega neko drugo s samih začetkov evropske drame: tisto, ki jo izvajajo Peržani v Ajshilovi istoimenski tragediji. ${ }^{49}$ Obred se ne izvaja neposredno v drami, temveč o njem izvemo posredno, iz dolge Kreontove pripovedi..$^{\circ}$ Opisi gozda, v katerem se izvaja obred, in obreda samega so izredno detajlirani: Senekovi stihi sami naslikajo scenerijo, ki bi jo težko posnela kakršna koli dejanska izvedba, pa čeprav podprta $\mathrm{z}$ računalniško simulacijo in laserskimi učinki.

\section{c) Znotrajdramska katarza}

Richard Buxton je opozoril, da so pomanjkljive tiste interpretacije Sofoklovega Kralja Ojdipa, ki ne upoštevajo zaključka drame - tistega, kar se zgodi po glasnikovi pripovedi (tj. od v. 1297 naprej)..$^{51}$ Epilog je zares pomemben $\mathrm{v}$ več ozirih, še posebej za temo človeškega vedenja, ${ }^{52}$ tu se tudi nekoliko poleže najhujši vihar Ojdipovega obupa; kljub temu pa ne moremo reči, da glavni lik znotraj drame doživi popolno očiščenje in pomiritev. Šele v zadnji Sofoklovi drami je njegov pogled na lastno preteklost umirjen in jasen: natanko razlikuje med subjektivno in objektivno krivdo.53

Drugače pa je pri Seneki. V zadnjih dveh dejanjih smo priče Ojdipovemu sprejetju nesprejemljivega: lastne krivde, ki si je še imenovati skoraj ne upa (pri tem je večkrat poudarjeno, da je incest še veliko večji greh od očetomora!). V smrti in samomoru vidi veliko prelahko, prehitro rešitev, zato si želi, da bi se narava spremenila (kakor jo je on sprevrgel s svojim grehom) tako, da bi se še velikokrat rodil in bi lahko potem še velikokrat doživel grozo in bo-

\footnotetext{
$46 \mathrm{Za}$ analizo dramske zgradbe Senekovega Ojdipa glej Schetter, "Senecas Oedipus-Tragödie«, 403-49.

47 Prim. 373-75.

48 Prim. 366-71.

49 Prim. Ajshil, Pers. 619-842.

50 Prim. Oed. 530-658.

51 Buxton, "What Can You Rely on in Oedipus Rex?«, 38

52 Prim. Calame, »Vision, Blindness, and Mask «, 17-37.

53 Prim. OC 240, 521, 539, 547, 964, 966.
} 
lečino smrti. ${ }^{54}$ Ker pa njegov svet ni ustrojen po budističnih predstavah, to ni mogoče; torej naj bo njegovo propadanje počasno in dolgo. Tudi tu je očitna ekstenzija motiva, ki naj poudari paroksizem bolečine. Tako si Ojdip izdre oči in o tem dejanju nam glasnik poroča na dolgo in natančno: o tem, kako si je z ukrivljenimi prsti trgal oči iz jamic, oči, ki jih je obenem upiral v svoje lastne prste ...55

Potem pa, ko nas zbor poduči o stoiškem nauku o nespremenljivosti usode,$^{56}$ se Ojdip presenetljivo hitro pomiri in začuti olajšanje. Nenadoma je konec njegove notranje izgubljenosti: čuti, da je odplačal svoj - še malo prej popolnoma nepredstavljivo visok - dolg. V slepoti je našel noč, ki odtehta težo njegovega krvoskrunstva, in na bogove se s prošnjo, naj prizanesejo domovini, že obrne kot zmagovalec. ${ }^{57}$

Tik pred koncem mu Jokasta sicer - že na meji groteske - predlaga, naj jo ubije, da bo postal tisto, kar mu še manjka - matero- in ženomorilec; nato uprizori krajšo dilemo o tem, kam naj se zabode - in po alegorični logiki (na veselje psihoanalitično nastrojenih filologov) potisne meč v svoj uterum capacem..$^{8} \mathrm{~A}$ zdi se, da Ojdipa to vendarle ne prizadene več, pa četudi njeno smrt prišteje na svoj rovaš - četudi je s tem še prekosil usodo in postavil Apolona na laž, saj ni ubil le očeta, ampak tudi mater. ${ }^{59}$ "Dobro je, končano je; tema mi dobro de, « je rekel pred Jokastinim miniprizorom. Zdaj z dodatno težo odhaja na negotovo pot izgnanstva (ali kar samoizgnanstva?) in vabi s seboj nasilno usodo, bolezen, sušico, kugo in bolečino. »Prijetno je imeti take vodnike!« se glasi sklepni verz. Je to skrajen sarkazem? Ne nujno: kajti Ojdip ne misli nase, ampak na Tebe. Ko bodo z njim odšli sadovi njegovih dejanj, bo lahko domovina zadihala čist zrak. Ko je prevzel vlogo grešnega kozla, je dosegel tudi katarzo. V znotrajdramskem času in prostoru.

Seneka je bil pesnik, a tudi filozof; sicer ekumensko odprt, a vendarle stoik. Zato morda ni brez pomena omeniti, da bi bila takšna interpretacija skladna z naukom stoiškega filozofa Aristona s Hiosa, da gledališka predstava, ki gledalca ne 'očisti' afektov, ni vredna več kot kopel, ki ne očisti. ${ }^{60}$ Ojdip na koncu drame je 'očiščen' afektov in celo izrecno altruistično usmerjen. Takšna znotrajdramska katarza se zdi zelo skladna s pedagoško obarvanim stoiškim pogledom na smoter poezije.

54 Prim. 945-47.

55 Prim. 952-79.

56 Prim. 980-94: „Omnia secto tramite vadunt, / primusque dies dedit extremum.« (»Vse giblje po določeni se poti, / in prvi dan določi zadnjega.«)

57 Prim. 974-75: »et victor deos / conclamat omnes«.

58 Prim. 1024-39.

59 Prim. 1042-46.

60 Plutarh, rect. rat. aud. 42b. Prim. tudi Egermann, »Seneca als Dichterphilosoph«, 53. 


\section{BIBLIOGRAFIJA}

Boyle, A. J. Roman Tragedy. London / New York: Routledge, 2006.

Buxton, R. »What Can You Rely on in Oedipus Rex? Response to Calame."V: Tragedy and the Tragic: Greek Theatre and Beyond, ur. M. S. Silk, 38-48. Oxford: Oxford University Press, 1996.

Calame, C. »Vision, Blindness, and Mask: The Radicalization of the Emotions in Sophocles' Oedipus Rex." V: Tragedy and the Tragic: Greek Theatre and Beyond, ur. M. S. Silk, 17-37. Oxford: Oxford University Press, 1996.

Davidson, D. "Kaj pomenijo metafore.« V: Kaj je metafora?, zbral, uredil in prevedel Božidar Kante, 191-210. Ljubljana: Krtina, 1998.

Egermann, F. »Seneca als Dichterphilosoph.« V: Senecas Tragödien, ur. E. Lefèvre, 33-57. Wege der Forschung. Darmstadt: Wissenschaftliche Buchgesellschaft, 1972.

Eliot, T. S. »Wesen, Tugenden und Schwächen der Tragödien Senecas.» Prevod D. Fehling. V: Senecas Tragödien, ur. E. Lefèvre, 22-32. Wege der Forschung. Darmstadt: Wissenschaftliche Buchgesellschaft, 1972.

Frank, M. »Besedilo in njegov slog.« Prevod A. Leskovec. Nova revija 26, št. 304-6 (2007): 208-24.

___ . —Kaj je literarno besedilo in kaj pomeni njegovo razumevanje?« Prevod A. Leskovec. Nova revija 26, št. 304-6 (2007): 225-76.

Friedrich, R. »Everything to Do with Dionysos? Ritualism, the Dionysiac, and the Tragic." V: Tragedy and the Tragic: Greek Theatre and Beyond, ur. M. S. Silk, 257-83. Oxford: Oxford University Press, 1996.

Griffin, J. »Sophocles and the Democratic City.« V: Sophocles Revisited, ur. J. Griffin, 7394. Oxford: Oxford University Press, 1999.

Gumbrecht, H. U. »Trenutek miru.« Prevod A. Leskovec. Nova revija 26, št. 301-3 (2007): $174-88$.

Heidegger, M. »Izvir umetniškega dela.« V: Izbrane razprave. Prevod I. Urbančič. Ljubljana: Cankarjeva založba, 1967.

Ingarden, R. Literarna umetnina. Prev. F. Jerman. Ljubljana: ŠKUC / Znanstveni inštitut Filozofske fakultete, 1990.

Ivanc, J. »Medeja: rimska tragedija.« V: Seneka: Medeja, prevedla, spremno besedo in opombe napisala J. Ivanc. Ljubljana: Modrijan, 2008.

Knox, B. M. W. »Euripides.« V: CHCL I, ur. P. E. Easterling in B. M. W. Knox, 316-39. Cambridge: Cambridge University Press, 1985.

Novak, F. G. Jr., ocena knjige George Steiner, Grammars of Creation. Studies in the Novel 34.4 (2002): 482.

Pickard-Cambridge, A. W. Dithyramb Tragedy and Comedy. Oxford: Clarendon Press, 1927.

Schetter, W. "Senecas Oedipus-Tragödie.« V: Senecas Tragödien, ur. E. Lefèvre, 402-49. Wege der Forschung. Darmstadt: Wissenschaftliche Buchgesellschaft, 1972.

Schlegel, A. W. "Vorlesungen über dramatische Kunst und Literatur.» V: Vorlesungen. 1. zv. Heidelberg: Mohr \& Zimmer, 1809. = "Senecas Tragödien." V: Senecas Tragödien, ur. E. Lefèvre, 13-14. Wege der Forschung. Darmstadt: Wissenschaftliche Buchgesellschaft, 1972.

Seaford, R. "Something to Do with Dionysos - Tragedy and the Dionysiac: Response to Friedrich." V: Tragedy and the Tragic: Greek Theatre and Beyond, ur. M. S. Silk, 284-94. Oxford: Oxford University Press, 1996. 
Senegačnik, B. »Klasična atiška tragedija.« V: Ajshil: Pribežnice, prevedel, opombe, komentar in spremno besedo napisal B. Senegačnik, 73-134. Celje: Celjska Mohorjeva družba, 2008.

Sommerstein, A. H. Aeschylean Tragedy. Bari: Levante, 1996.

—_. Theatron. Teatro greco. Bari: Levante, 2000.

Steiner, G. Grammars of Creation. New Haven: Yale University Press, 2001.

Steiner, G. Smrt tragedije. Prevod K. Jerin. Zbirka Labirinti. Ljubljana: LUD Literatura, 2002.

Trevet, N. Commento all' Oedipus di Seneca, izd. A. Lagioia. Quaderni di Invigilata Lucernis 35. Bari: Edipuglia, 2008.

Veber, F. Estetika. Slovenska filozofska misel 2. Ljubljana: Slovenska Matica, 1985.

Zuntz, G. The political plays of Euripides. Manchester: Manchester University Press, 1955.

\section{OEDIPUS THE KING BY SOPHOCLES AND SENECA: THE CULTURAL, HISTORICAL AND INDIVIDUAL ASPECTS OF HERMENEUTICS}

\section{Summary}

A comparison between Sophocles' and Seneca's Oedipus the King affords large scope for illuminating the similarities and contrasts between their respective cultural milieus. The generic and thematic similarity of the works (which, of course, points to the embeddedness of Roman drama in the Greek genre) helps to set off the enormous cultural differences: the social function of the theatre, the conception of myth, and the religious and spiritual horizons in the early Roman Empire vastly differed from those of the classical Athens. It is only against the background of these general cultural differences that the issue most interesting to literary hermeneutics can be estimated: the irreducibly individual feature of either author, Sophocles or Seneca - his style.

Seneca's plays, regardless of their (un)stageability, are strongly rhetorical. The extensions of certain motifs of the traditional myth (description of the plague at Thebes), their inventive reworking, and narrative digressions (divination using entrails, description of the forest, rite of evoking the dead) significantly slow down the dramatic action. The scenes are thus often lengthy and static, yet at the same time meticulously and evocatively elaborated as images of the external and internal worlds. The effects of the characters' extensive psychological self-illuminations in their monologues sometimes run counter to dramaturgical logic, a feature which sets Seneca's Oedipus most clearly apart from Sophocles'. Given this striking extensiveness, the reconciliation of Seneca's tragic hero to his fate seems the more surprising: a likely motive for it is the pedagogical principle of Stoic poetic, according to which the spectator is 'purified' of his affects through the catharsis which is experienced by the characters within the dramatic space and time. 